\title{
Penerapan Model Pembelajaran Inkuiri Berbasis Media Virtual Program Java Pada Guru Fisika Dan Siswa SMA
}

\author{
Susilawati $^{1}{ }^{*}$, Aris Doyan ${ }^{1}$, Ahmad Harjono ${ }^{1}$, Kosim $^{1}$ \\ ${ }^{I}$ Program Studi Pendidikan Fisika FKIP Universitas Mataram, Mataram, Nusa Tenggara Barat, Indonesia
}

*Corresponding Author: Susilawati Universitas Mataram, Mataram, Indonesia;

Email:susilawatihambali@unram.ac.id

\begin{abstract}
Abstrak: Kegiatan pengabdian pada masyarakat ini bertujuan untuk meningkatkan pemahaman guru dan siswa tentang pembelajaran inkuiri berbasis media virtual program java pada mata pelajaran fisika. Adapun materi fisika yang disampaikan dalam pengabdian ini terdiri dari gerak benda, percepatan benda dan hukum Newton, serta gerak jatuh bebas. Secara umum kegiatan pelatihan ini berhasil dan terlaksana dengan baik, karena guru-guru fisika yang menjadi peserta merasa mendapatkan bekal cara-cara menyampaikan materi fisika menggunakan model inkuiri berbasis media virtual program java dan termotivasi untuk menerapkannya dalam pembelajaran di kelas. Selain itu, di akhir pertemuan mereka menginginkan kegiatan ini berkelanjutan untuk penguatan konsep fisika bagi guru SMA.
\end{abstract}

Kata Kunci:Pembelajaran Inkuiri; Media Virtual Program Java

\section{Pendahuluan}

Fisika merupakan salah satu cabang IPA yang mempelajari tentang keteraturan alam dan manfaatnya dalam perkembangan ilmu pengetahuan dan teknologi. Pembelajaran fisika tidak hanya mempelajari teori, prinsip maupun produk lainnya, melainkan juga merupakan proses berpikir dan berubahnya tingkah laku menuju arah yang lebih baik (Hartono, 2006).

Berdasarkan kurikulum tingkat satuan pendidikan tujuan pembelajaran IPA-fisika dalam kurikulum mata pelajaran IPA di SMA/MA adalah: (1) Meningkatkan keyakinan terhadap kebesaran Tuhan Yang Maha Esa berdasarkan keberadaan, keindahan dan keteraturan ciptaaanNya; (2) mengembangkan pemahaman tentang berbagai macam gejala alam, konsep dan prinsip IPA yang bermanfaat dan dapat diterapkan dalam kehidupan sehari-hari; (3) mengembangkan rasa ingin tahu, sikap positif, dan kesadaran terhadap adanya hubungan saling mempengaruhi antara IPA, lingkungan, teknologi, dan masyarakat; (4) melakukan inkuiri ilmiah untuk menumbuhkan kemampuan berpikir, bersikap dan bertindak ilmiah serta berkomunikasi; (5) meningkatkan kesadaran untuk berperanserta dalam memelihara, menjaga, dan melestarikan lingkungan serta sumber daya alam; 6) Meningkatkan kesadaran untuk menghargai alam dan segala keteraturannya sebagai salah satu ciptaan Tuhan; (7) meningkatkan pengetahuan, konsep, dan keterampilan IPA sebagai dasar untuk melanjutkan pendidikan ke jenjang selanjutnya.Berdasarkan pendapat tersebut dapat diketahui bahwa pembelajaran fisika di SMA/MA merupakan mata pelajaran wajib bagi siswa pada jurusan IPA. Salah satu tujuannya adalah melakukan inkuiri ilmiah untuk menumbuhkan sikap ilmiah yaitu jujur, objektif, terbuka, ulet, kritis, dan dapat bekerjasama dengan orang lain. Dalam penentuan kelulusan siswa, mata pelajaran IPA fisika ditentukan berdasarkan hasil yang dicapai siswa dalam ujian nasional (UN) dengan nilai minimal 5,0.

Pencapaian hasil belajar fisika dan kelompok IPA siswa SMA di Kota Mataram yang diamati sejak tahun 2009 sampai dengan tahun 2011, pada umumnya termasuk dalam kategori rendah (Dinas Dikpora Propinsi NTB). Ada beberapa faktor yang diduga sebagai penyebab rendahnya pencapaian belajar siswa dalam mata pelajaran kelompok IPA antara lain: (1) mata pelajaran ini membutuhkan kemampuan berpikir tingkat tinggi, (2) penguasaan materi pelajaran membutuhkan pelatihan pemecahan masalah, dan (3) model pembelajaran yang diterapkan guru masih lebih banyak berpusat pada guru (teacher centered).

Arah perkembangan perspektif kehidupan kelas sedang bergerak menuju penciptaan iklim kelas yang memungkinkan siswa dapat menggali dan menemukan pengetahuan mereka sendiri atau siswa dituntut memiliki kemampuan dalam menemukan dan menyelidiki sendiri tentang suatu 
permasalahan dalam belajar. Dengan demikian rangkaian kegiatan pembelajaran yang menekankan pada proses berpikir secara kritis dan analitis untuk mencari dan menemukan sendiri jawaban dari suatu masalah yang dipertanyakan tidak terlepas dari harapan agar siswa mempunyai pengalaman dalam pembelajaran inkuiri. Model Pembelajaran inkuiri merupakan suatu model pembelajaran yang mengajak siswa untuk menemukan jawaban dari permasalahan yang ditemukan oleh dirinya sendiri (Dimyati, 2011).Dalam rangka desiminasi hasilhasil penelitian dan penerapan model pembelajaran inkuiri, Tim Pengusul mengajukan satu kegiatan pengabdian pada masyarakat dalam bentuk pelatihan dan praktik pada guru-guru fisika di SMA Negeri 5 Mataram dengan judul: "Penerapan Model Pembelajaran Inkuiri Berbasis Media Virtual Program Java pada guru fisika dan siswa SMA Negeri 5 Mataram tahun 2019”.

\section{Metode Pelaksanaan}

Menindak lanjuti permasalahan tersebut telah diadakan kegiatan pengabdian pada masyarakat untuk guru-guru fisika di SMA Negeri 5 Mataram dengan langkah-langkah sebagai berikut: Pelaksanaan kegiatan diawali dengan pertemuan antara dosen dan guru bidang studi fisika membahas tentang model pembelajaran inkuiri berbasis virtual program java, dan cara menggunakan media virtual tesebut. Selanjutnya membahas dan menetapkan hari untuk pengajaran di kelas dengan kolaborasi antara guru bidang studi dan dosen masuk bersama-sama mengikuti pembelajaran inkuiri tesebut. Tahapan-tahapan yang dilakukan sebagai berikut: pemberian materi yang terdiri dari gerak benda, percepatan benda, hukum Newton, dan gerak jatuh bebas.

\section{Hasil dan Pembahasan}

Pelaksanaan kegiatan diawali dengan pertemuan antara dosen dan guru bidang studi fisika membahas tentang model pembelajaran inkuiri berbasis virtual program java, dan cara menggunakan media virtual tesebut. Adapun materi yang disampaikan terdiri dari gerak benda, percepatan benda, hukum Newton, dan gerak jatuh bebas.Berikut ini adalah beberapa gambar yang berkaitan dengan materi gerak dapat dilihat pada gambar 1.
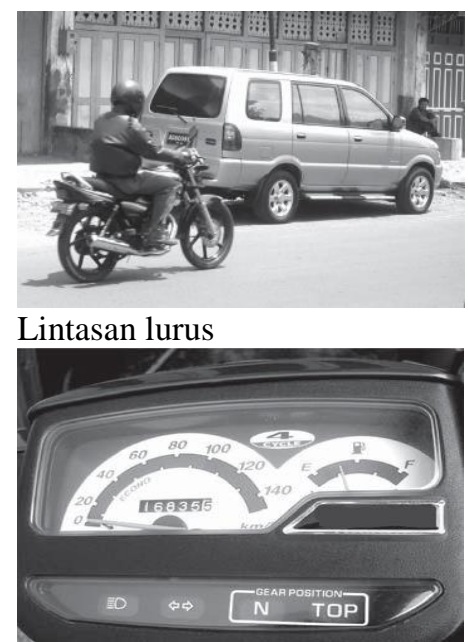

Kecepatan spedometer

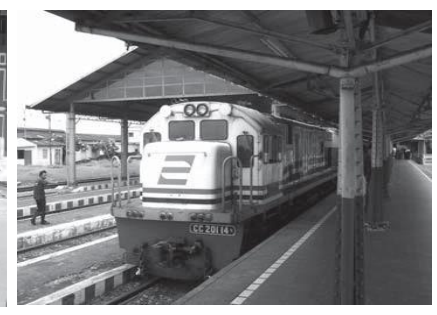

Gerak relatif

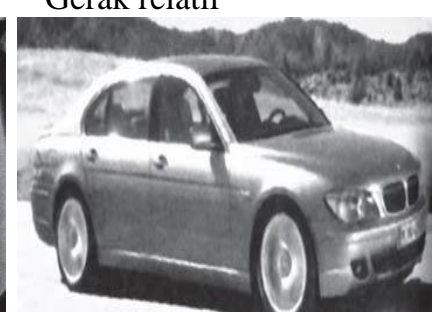

Gerak lurus beraturan
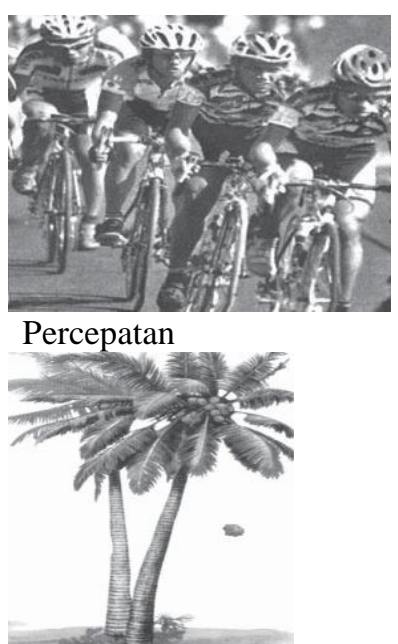

Gerak lurus berubah beraturan

Gambar 1. Contoh penerapan gerak dalam kehidupan

Tim dosen yang berperan sebagai narasumber terdidri dari empat orang yaitu Drs. Aris Doyan, M.Si., Ph.D dan Dra. Susilawati, M.Si.Ph.D, Dr. rer.nat Kosim, M. Si dan Dr. Ahmad Harjono. Adapun tugas dari masing-masing narasumber yaitu Drs. Aris Doyan menyampaikan materi tentang gerak benda dan gerak lurus berubah beraturan; Dra. Susilawati M.Si.Ph.D menyampaikan materi tentang percepatan benda dan Hukum Newton; Dr. rer.nat Kosim, M. Si meyampaikan materi tentang gerak lurus berubah beraturan; dan Dr. Ahmad Harjono, M.Pd menyampaikan materi tentang gerak jatuh bebas. Tahapan-tahapan pembelajaranmasing-masing materi dapat dilihat pada tabel 1,tabel 2, tabel 3, dan tabel 4 . 
Tabel 1. Tahapan pembelajaran materi tentang gerak benda dan gerak lurus berubah beraturan

\begin{tabular}{|c|c|c|c|}
\hline No & Tahap pembelajaran & Kegiatan guru dan Dosen & Kegiatan siswa \\
\hline \multirow[t]{2}{*}{1} & Penyajian masalah & Guru menyajikan permasalahan & $\begin{array}{l}\text { Memahami dan mencermati permasalahan Gerak } \\
\text { benda, Jarak, perpindahan, kelajuan, kecepatan, } \\
\text { kecepatan rata-rata. }\end{array}$ \\
\hline & & $\begin{array}{l}\text { Menjelaskan langkah-langkah } \\
\text { inkuiri pada materi gerak benda, } \\
\text { Jarak, perpindahan, kelajuan, } \\
\text { kecepatan, kecepatan rata-rata. }\end{array}$ & $\begin{array}{l}\text { Memahami prosedur/langkah langkah inkuiri pada } \\
\text { materi Gerak benda, Jarak, perpindahan, kelajuan, } \\
\text { kecepatan, kecepatan rata-rata. }\end{array}$ \\
\hline \multirow[t]{3}{*}{2} & $\begin{array}{l}\text { Pengumpulan data } \\
\text { verifikasi }\end{array}$ & $\begin{array}{lcc}\text { Membimbing } & \text { siswa } & \text { untuk } \\
\text { mengumpulkan } & \text { informasi } & \text { gerak } \\
\text { benda } & & \end{array}$ & $\begin{array}{l}\text { Melakukan pengumpulan informasi/data tentang } \\
\text { gerak benda }\end{array}$ \\
\hline & & $\begin{array}{l}\text { Membimbing cara-cara mencari } \\
\text { data perpindahan }\end{array}$ & Melakukan pengumpulan data \\
\hline & & $\begin{array}{l}\text { Membimbing mengklasfikasi data } \\
\text { kelajuan }\end{array}$ & $\begin{array}{l}\text { Mengumpulkan data sesuai dengan katagorisasi } \\
\text { permasalahan }\end{array}$ \\
\hline \multirow[t]{5}{*}{3} & $\begin{array}{l}\text { Pengumpulan data } \\
\text { eksperimentasi }\end{array}$ & $\begin{array}{l}\text { Membimbing siswa melakukan } \\
\text { eksperimen perpindahan }\end{array}$ & Melakukan eksperimen \\
\hline & & $\begin{array}{l}\text { Membimbing siswa mengatur } \\
\text { data kecepatan rata-rata }\end{array}$ & $\begin{array}{l}\text { Melakukan pengaturan data yang selanjutnya } \\
\text { dilakukan eksperimen }\end{array}$ \\
\hline & & $\begin{array}{l}\text { Membimbing dan mengarahkan } \\
\text { pertanyaan-pertanyaan siswa } \\
\text { tentang gerak }\end{array}$ & $\begin{array}{l}\text { Melakukan pertanyaan-pertanyaan terkait dengan } \\
\text { eksperimen yang dilakukan }\end{array}$ \\
\hline & & $\begin{array}{l}\text { Membimbing siswa mengamati } \\
\text { perubahan yang terjadi pada } \\
\text { kecepatan rata-rata }\end{array}$ & Mencatat dan menganalisis hasil eksperimen \\
\hline & & $\begin{array}{l}\text { Menumbuhkan dan meningkatkan } \\
\text { interaksi antar siswa dan terjadi } \\
\text { interaksi dalam penyelesaian soal } \\
\text { tentang gerak }\end{array}$ & $\begin{array}{l}\text { Berinteraksi dan bekerjasama sesama anggota } \\
\text { kelompok dalam menyelesaikan tugas pembelajaran }\end{array}$ \\
\hline \multirow[t]{2}{*}{4} & $\begin{array}{l}\text { Organisasi data dan } \\
\text { formulasi }\end{array}$ & $\begin{array}{l}\text { Membimbing siswa melakukan } \\
\text { penataan data/hasil eksperimen }\end{array}$ & $\begin{array}{l}\text { Melakukan penataan/interpretasi terhadap hasil } \\
\text { eksperimen }\end{array}$ \\
\hline & kesimpulan & $\begin{array}{l}\text { Membimbing siswa untuk } \\
\text { membuat suatu kesimpulan }\end{array}$ & Membuat kesimpulan \\
\hline \multirow[t]{2}{*}{5} & $\begin{array}{l}\text { Analisis proses } \\
\text { inkuiri }\end{array}$ & $\begin{array}{l}\text { Membimbing siswa untuk } \\
\text { memahami pola-pola penemuan } \\
\text { yang telah dilakukan }\end{array}$ & Memperhatikan pola-pola eksperimen \\
\hline & & $\begin{array}{l}\text { Membimbing siswa melihat } \\
\text { kelemahan dan kesalahan yang } \\
\text { terjadi pada gerak benda }\end{array}$ & $\begin{array}{l}\text { Menganalisis kelemahan dan kesalahan yang } \\
\text { mungkin terjadi dalam proses eksperimen dan } \\
\text { mencocokkan dengan hasil perhitungan teori }\end{array}$ \\
\hline
\end{tabular}

Tabel 2. Tahapan pembelajaran materi tentang percepatan benda dan Hukum Newton

\begin{tabular}{ll}
\hline No & Tahap Pembelajaran \\
\hline 1 & Penyajian masalah \\
2 & $\begin{array}{l}\text { Pengumpulan data } \\
\text { verifikasi }\end{array}$
\end{tabular}
Kegiatan guru dan dosen Guru menyajikan permasalahan

Menjelaskan prosedur/langkahlangkah inkuiri pada materi percepatan dan Hukum Newton Membimbing siswa untuk mengumpulkan informasi percepatan dan Hukum Newton

Membimbing cara-cara mencari data percepatan dan Hukum Newton . Membimbing mengklasfikasi data percepatan dan Hukum Newton .

3 Pengumpulan data eksperimentasi
Membimbing siswa melakukan eksperimen percepatan dan Hukum Newton .

Membimbing siswa mengatur data percepatan dan Hukum Newton .
Kegiatan siswa

Memahami dan mencermati permasalahan percepatan dan Hukum Newton .

Memahami prosedur/langkah langkah inkuiri pada materi percepatan dan Hukum Newton.

Melakukan pengumpulan informasi/data percepatan dan Hukum Newton.

Melakukan pengumpulan data

Mengumpulkan data sesuai dengan katagorisasi permasalahan

Melakukan eksperimen

Melakukan pengaturan data yang selanjutnya dilakukan eksperimen 


\begin{tabular}{|c|c|c|c|}
\hline No & Tahap Pembelajaran & Kegiatan guru dan dosen & Kegiatan siswa \\
\hline \multirow{5}{*}{4} & \multirow{5}{*}{$\begin{array}{l}\text { Organisasi data dan } \\
\text { formulasi kesimpulan }\end{array}$} & $\begin{array}{l}\text { Membimbing dan mengarahkan } \\
\text { pertanyaan-pertanyaan siswa tentang } \\
\text { percepatan dan Hukum Newton. }\end{array}$ & $\begin{array}{l}\text { Melakukan pertanyaan-pertanyaan terkait } \\
\text { dengan eksperimen yang dilakukan }\end{array}$ \\
\hline & & $\begin{array}{l}\text { Membimbing siswa mengamati } \\
\text { perubahan yang terjadi pada } \\
\text { kecepatan rata-rata }\end{array}$ & Mencatat dan menganalisis hasil eksperimen \\
\hline & & $\begin{array}{l}\text { Menumbuhkan dan meningkatkan } \\
\text { interaksi antar siswa dan terjadi } \\
\text { interaksi dalam penyelesaian soal } \\
\text { tentang percepatan dan Hukum } \\
\text { Newton }\end{array}$ & $\begin{array}{l}\text { Berinteraksi dan bekerjasama sesama } \\
\text { anggota kelompok dalam menyelesaikan } \\
\text { tugas pembelajaran }\end{array}$ \\
\hline & & $\begin{array}{l}\text { Membimbing siswa melakukan } \\
\text { penataan data/hasil eksperimen }\end{array}$ & $\begin{array}{l}\text { Melakukan penataan/interpretasi terhadap } \\
\text { hasil eksperimen }\end{array}$ \\
\hline & & $\begin{array}{l}\text { Membimbing siswa untuk membuat } \\
\text { suatu kesimpulan }\end{array}$ & Membuat kesimpulan \\
\hline \multirow[t]{2}{*}{5} & \multirow[t]{2}{*}{ Analisis proses inkuiri } & $\begin{array}{l}\text { Membimbing siswa untuk memahami } \\
\text { pola-pola penemuan yang telah } \\
\text { dilakukan }\end{array}$ & Memperhatikan pola-pola eksperimen \\
\hline & & $\begin{array}{l}\text { Membimbing siswa melihat } \\
\text { kelemahan dan kesalahan yang terjadi } \\
\text { pada percepatan dan Hukum Newton }\end{array}$ & $\begin{array}{l}\text { Menganalisis kelemahan dan kesalahan yang } \\
\text { mungkin terjadi dalam proses eksperimen } \\
\text { dan mencocokkan dengan hasil perhitungan } \\
\text { teori }\end{array}$ \\
\hline
\end{tabular}

Tabel 3.Tahapan pembelajaran materi tentang gerak lurus berubah beraturan.

\begin{tabular}{|c|c|c|c|}
\hline No & Tahap Pembelajaran & Kegiatan guru dan Dosen & Kegiatan siswa \\
\hline \multirow[t]{2}{*}{1} & Penyajian masalah & Guru menyajikan permasalahan & $\begin{array}{l}\text { Memahami dan mencermati permasalahan } \\
\text { gerak lurus berubah beraturan }\end{array}$ \\
\hline & & $\begin{array}{l}\text { Menjelaskan prosedur/langkah- } \\
\text { langkah inkuiri pada materi gerak } \\
\text { lurus berubah beraturan }\end{array}$ & $\begin{array}{l}\text { Memahami prosedur/langkah langkah } \\
\text { inkuiri pada materi gerak lurus berubah } \\
\text { beraturan }\end{array}$ \\
\hline \multirow[t]{3}{*}{2} & $\begin{array}{l}\text { Pengumpulan data } \\
\text { verifikasi }\end{array}$ & $\begin{array}{l}\text { Membimbing siswa untuk } \\
\text { mengumpulkan informasi gerak } \\
\text { lurus berubah beraturan }\end{array}$ & $\begin{array}{l}\text { Melakukan pengumpulan informasi/data } \\
\text { gerak lurus berubah beraturan }\end{array}$ \\
\hline & & $\begin{array}{l}\text { Membimbing cara-cara mencari } \\
\text { data gerak lurus berubah beraturan }\end{array}$ & Melakukan pengumpulan data \\
\hline & & $\begin{array}{l}\text { Membimbing mengklasfikasi data } \\
\text { gerak lurus berubah beraturan }\end{array}$ & $\begin{array}{l}\text { Mengumpulkan data sesuai dengan } \\
\text { katagorisasi permasalahan }\end{array}$ \\
\hline \multirow[t]{5}{*}{3} & $\begin{array}{l}\text { Pengumpulan data } \\
\text { eksperimentasi }\end{array}$ & $\begin{array}{l}\text { Membimbing siswa melakukan } \\
\text { eksperimen gerak lurus berubah } \\
\text { beraturan }\end{array}$ & Melakukan eksperimen \\
\hline & & $\begin{array}{l}\text { Membimbing siswa mengatur data } \\
\text { gerak lurus berubah beraturan }\end{array}$ & $\begin{array}{l}\text { Melakukan pengaturan data yang } \\
\text { selanjutnya dilakukan eksperimen }\end{array}$ \\
\hline & & $\begin{array}{l}\text { Membimbing dan mengarahkan } \\
\text { pertanyaan-pertanyaan siswa } \\
\text { tentang gerak lurus berubah } \\
\text { beraturan }\end{array}$ & $\begin{array}{l}\text { Melakukan pertanyaan-pertanyaan terkait } \\
\text { dengan eksperimen yang dilakukan }\end{array}$ \\
\hline & & $\begin{array}{l}\text { Membimbing siswa mengamati } \\
\text { perubahan yang terjadi pada gerak } \\
\text { lurus berubah beraturan }\end{array}$ & $\begin{array}{l}\text { Mencatat dan menganalisis hasil } \\
\text { eksperimen }\end{array}$ \\
\hline & & $\begin{array}{l}\text { Menumbuhkan dan meningkatkan } \\
\text { interaksi antar siswa dan terjadi } \\
\text { interaksi dalam penyelesaian soal } \\
\text { tentang gerak lurus berubah } \\
\text { beraturan }\end{array}$ & $\begin{array}{l}\text { Berinteraksi dan bekerjasama sesama } \\
\text { anggota kelompok dalam menyelesaikan } \\
\text { tugas pembelajaran }\end{array}$ \\
\hline \multirow[t]{2}{*}{4} & $\begin{array}{l}\text { Organisasi data dan } \\
\text { formulasi kesimpulan }\end{array}$ & $\begin{array}{l}\text { Membimbing siswa melakukan } \\
\text { penataan data/hasil eksperimen }\end{array}$ & $\begin{array}{l}\text { Melakukan penataan/interpretasi terhadap } \\
\text { hasil eksperimen }\end{array}$ \\
\hline & & $\begin{array}{l}\text { Membimbing siswa untuk } \\
\text { membuat suatu kesimpulan }\end{array}$ & Membuat kesimpulan \\
\hline 5 & Analisis proses inkuiri & Membimbing siswa untuk & Memperhatikan pola-pola eksperimen \\
\hline
\end{tabular}




\begin{tabular}{lll}
\hline No Tahap Pembelajaran & Kegiatan guru dan Dosen & Kegiatan siswa \\
\hline & memahami pola-pola penemuan & \\
& yang telah dilakukan & \\
& Membimbing siswa melihat & Menganalisis kelemahan dan kesalahan \\
& kelemahan dan kesalahan yang & yang mungkin terjadi dalam proses \\
& terjadi pada gerak lurus berubah & eksperimen dan mencocokkan dengan \\
& beraturan & hasil perhitungan teori \\
\hline
\end{tabular}

Tabel 4. Tahapan pembelajaran materi tentang gerak jatuh bebas

\begin{tabular}{|c|c|c|}
\hline No & Tahap pembelajaran & Kegiatan guru dan Dosen \\
\hline \multirow[t]{2}{*}{1} & Penyajian masalah & Guru menyajikan permasalahan \\
\hline & & $\begin{array}{l}\text { Menjelaskan prosedur/langkah- } \\
\text { langkah inkuiri pada materi gerak } \\
\text { jatuh bebas }\end{array}$ \\
\hline \multirow[t]{3}{*}{2} & $\begin{array}{l}\text { Pengumpulan data } \\
\text { verifikasi }\end{array}$ & $\begin{array}{l}\text { Membimbing siswa untuk } \\
\text { mengumpulkan informasi gerak } \\
\text { jatuh bebas. }\end{array}$ \\
\hline & & $\begin{array}{l}\text { Membimbing cara-cara mencari } \\
\text { data gerak jatuh bebas }\end{array}$ \\
\hline & & $\begin{array}{l}\text { Membimbing mengklasfikasi data } \\
\text { gerak jatuh bebas }\end{array}$ \\
\hline \multirow[t]{5}{*}{3} & $\begin{array}{l}\text { Pengumpulan data } \\
\text { eksperimentasi }\end{array}$ & $\begin{array}{l}\text { Membimbing siswa melakukan } \\
\text { eksperimen gerak jatuh bebas }\end{array}$ \\
\hline & & $\begin{array}{l}\text { Membimbing siswa mengatur data } \\
\text { gerak jatuh bebas }\end{array}$ \\
\hline & & $\begin{array}{l}\text { Membimbing dan mengarahkan } \\
\text { pertanyaan-pertanyaan siswa } \\
\text { tentang gerak jatuh bebas }\end{array}$ \\
\hline & & $\begin{array}{l}\text { Membimbing siswa mengamati } \\
\text { perubahan yang terjadi pada gerak } \\
\text { jatuh bebas }\end{array}$ \\
\hline & & $\begin{array}{l}\text { Menumbuhkan dan meningkatkan } \\
\text { interaksi antar siswa dan terjadi } \\
\text { interaksi dalam penyelesaian soal } \\
\text { tentang gerak jatuh bebas }\end{array}$ \\
\hline \multirow[t]{2}{*}{4} & $\begin{array}{l}\text { Organisasi data dan } \\
\text { formulasi kesimpulan }\end{array}$ & $\begin{array}{l}\text { Membimbing siswa melakukan } \\
\text { penataan data/hasil eksperimen }\end{array}$ \\
\hline & & $\begin{array}{l}\text { Membimbing siswa untuk membuat } \\
\text { suatu kesimpulan }\end{array}$ \\
\hline \multirow[t]{4}{*}{5} & Analisis proses inkuiri & Membimbing siswa untuk \\
\hline & & $\begin{array}{l}\text { memahami pola-pola penemuan } \\
\text { yang telah dilakukan }\end{array}$ \\
\hline & & Membimbing siswa melihat \\
\hline & & $\begin{array}{l}\text { kelemahan dan kesalahan yang } \\
\text { terjadi pada gerak jatuh bebas }\end{array}$ \\
\hline
\end{tabular}

Kegiatan siswa

Memahami dan mencermati permasalahan gerak jatuh bebas

Memahami prosedur/langkah langkah inkuiri pada materi gerak jatuh bebas

Melakukan pengumpulan informasi/data gerak jatuh bebas.

Melakukan pengumpulan data

Mengumpulkan data sesuai dengan katagorisasi permasalahan

Melakukan eksperimen

Melakukan pengaturan data yang selanjutnya dilakukan eksperimen Melakukan pertanyaan-pertanyaan terkait dengan eksperimen yang dilakukan

Mencatat dan menganalisis hasil eksperimen

Berinteraksi dan bekerjasama sesama anggota kelompok dalam menyelesaikan tugas pembelajaran

Melakukan penataan/interpretasi terhadap hasil eksperimen

Membuat kesimpulan

Memperhatikan pola-pola eksperimen

Menganalisis kelemahan dan kesalahan yang mungkin terjadi dalam proses eksperimen dan mencocokkan dengan hasil perhitungan teori

Berikut ini adalah dokumentasi dari proses pembelajaran yang dilakukan dengan model inkuiri berbasis media virtual program java dapat dilihat pada gambar 2 . 


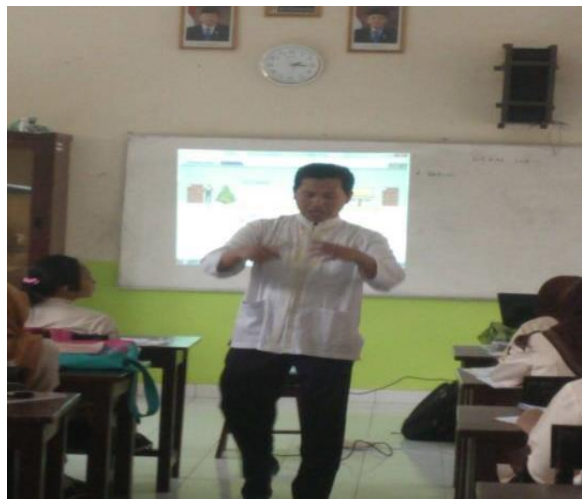

a. Guru Menyajikan masalah

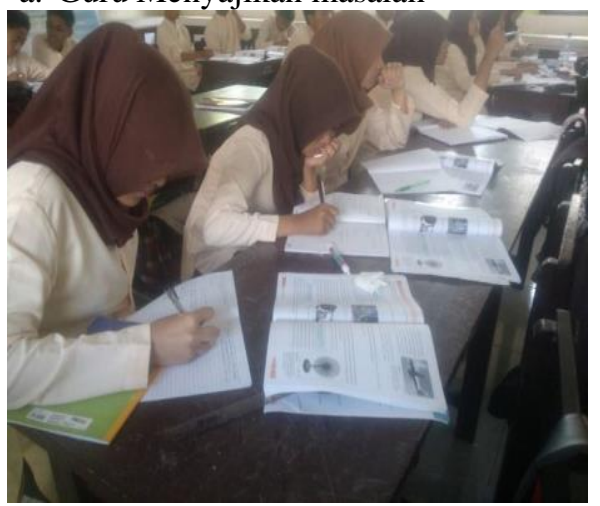

c. Mengmpulkan data eksperimentasi

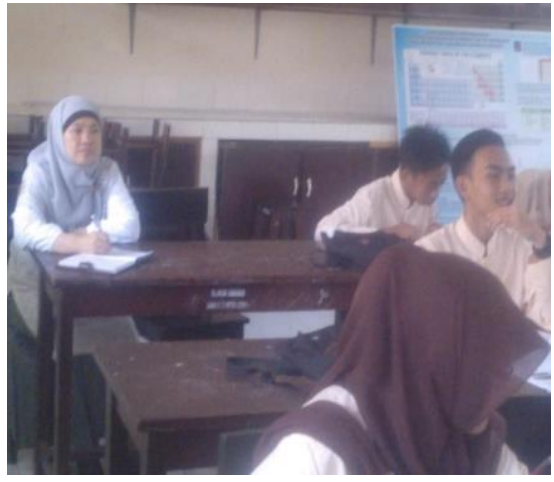

b. Mengumpulkan data verifikasi

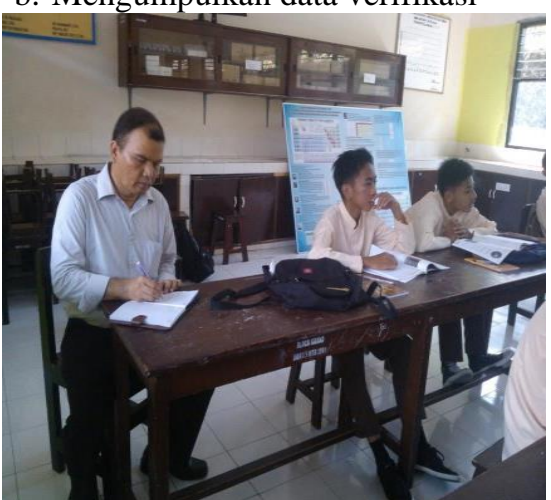

d. Organisasi data dan formulasi kesimpulan

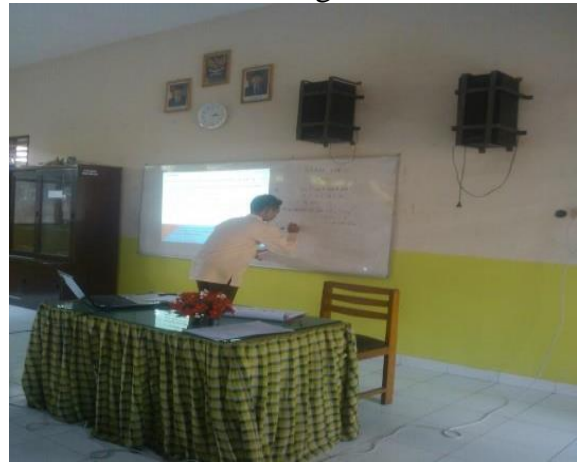

e. Analisis proses inkuiri

Gambar 2. Tahapan pada pembelajaran inkuiri

Tujuan kegiatan penyajian materi dan diskusi yang telah dilaksanakan adalah memberikan pemahaman peserta tentang pelajaran fisika yang disampaikan dengan model pembelajaran inkuiri berbasis media virtual program java . berikut ini Hasil penyajian materi dan diskusi yang telah dilakukan pada kegiatan pengabdian ini meliputi: (1) secara umum kegiatan diskusi berlangsung sangat baik; (2) respon peserta maupun tanggapan dari nara sumber berlangsung baik; (3) peserta bersungguh-sungguh dan sangat antusias mengikuti tahap demi tahap sajian materi pelatihan yang samapaikan oleh nara sumber: (4) respon positif dari peserta terhadap materi pelatihan ditandai oleh banyaknya pertanyaan yang muncul dari peserta.

\section{Kesimpulan}

Secara umum kegiatan pelatihan ini berhasil dan terlaksana dengan baik, karena guruguru Fisika yang menjadi peserta merasa mendapatkan bekal cara-cara menyampaikan materi fisika menggunakan model inkuiri berbasis media virtual program java dan termotivasi untuk mencoba menerapkannya dalam pembelajaran di kelas. Selain itu di akhir pertemuan mereka menginginkan kegiatan ini berkelanjutan untuk penguatan konsep fisika bagi guru SMA.

\section{Saran}

Pelatihan materi Fisikadengan model pembelajaran inkuiri berbasis media virtual program java ini sudah berjalan dengan lancar, namun dalam kegiatan hendaknya disajikan media 
pembelajaran untuk membantu siswa dalam memahami materi.

\section{Ucapan Terima Kasih}

Tim pengabdian mengucapkan terima kasih kepada kementerian riset, teknologi, dan pendidikan tinggi yang telah membiayai kegiatan pengabdian ini, serta kepala sekolah SMA Negeri 5 yang telah mendukung kegiatan ini.

\section{Daftar Pustaka}

Adnane, M.,Al Idrus, Agil, dkk. 2007. Strategi Pembelajaran (Modul Diklat Sertifikasi Guru). Mataram: Universitas Mataram.

Amri,Sofan. 2011. Proses Pembelajaran Kreatif Dan Inofatif Dalam Kelas. Jakarta: Pustakaraya

Bruce Joice-Marsha Weil. 2000. Models of Teaching. USA: Allyn \& Bacon.

Dimyati, M \& Mujiono. 2011. Belajar dan Pembelajaran. Jakarta: Rineka Cipta.

Hamalik, Oemar. 2009. Proses Blajar Mengajar. Jakarta: Bumi Aksar.

Hartono.2006. Pembelajaran Fisika Modern Bagi Mahasiswa Calon Guru.Disertasi Doktor pada SPs UPI Bandung: tidak diterbitkan.

Sanjaya, Wina. 2006. Strategi Pembelajaran Berorientasi Standar Proses Pendidikan. Jakarta: Kencana Prenada Media Group.

Trianto. 2007. Model Pembelajaran Terpadu: Konsep, Strategi, dan Implementasi dalam KTSP. Jakarta: Bumi Aksara. 